\title{
STATUS OF THE POPULATION STRUCTURE OF THE MANGROVE CRAB UCIDES CORDATUS (DECAPODA: OCYPODIDAE) ON THE PIRAQUÊ-AÇU RIVER ESTUARY, ESPÍRITO SANTO, BRAZIL
}

\author{
Rita de Cássia Conti ${ }^{I}$ and Rosebel Cunha Nalesso ${ }^{2 *}$
}

${ }^{1}$ Secretaria de Meio ambiente de Aracruz

(Av. Morobá, s.n; 29.102-770 Morobá, Aracruz, ES, Brasil)

rcassiaconti@gmail.com

${ }^{2}$ Universidade Federal do Espírito Santo - Departamento de Oceanografia e Ecologia

*Corresponding author: rosebel.nalesso@terra.com.br

\begin{abstract}
A B S TR A C T
The land crab Ucides cordatus is a keystone species of neotropical mangrove forests and an important resource of the artisanal fisheries. The spatial and temporal distribution of $U$. cordatus in the mangrove area of the Piraquê-açu river estuary was determined following a longitudinal estuarine salinity gradient (lower, middle, upper estuary) and along the vertical intertidal gradient. The numbers of open and closed burrows were counted monthly on fixed transects, the inhabiting crabs were caught, sexed and the carapace width measured, during 1 year. The mean crab density was 2.5 ind. $\mathrm{m}^{-2}$. The highest crab density ( 3.9 ind. $\mathrm{m}^{-2}$ ), linked to high numbers of juvenile crabs, was found on the upper estuary and correlated with lower salinities. High intertidal levels had higher crab densities than lower intertidal levels, except in the upper estuary. Males were smaller than females; the mean carapace width of the population was $4.89 \mathrm{~cm}$, below the minimum legal harvesting size (6 $\mathrm{cm}$ ). The predominance of females over males at some sites (especially close to villages) brought out the advanced level of overfishing of this $U$. cordatus population and highlights the urgent need of management actions.
\end{abstract}

\section{R E S U M O}

O caranguejo Ucides cordatus é uma espécie chave nos manguezais da região neotropical e um importante recurso pesqueiro para populações tradicionais. A distribuição espacial e temporal de $U$. cordatus no manguezal do Rio Piraquê-açu foi estudada ao longo de um gradiente de salinidade, no estuário inferior, médio e superior na faixa entre-marés. Mensalmente durante um ano. O número de tocas abertas e fechadas ao longo de transectos fixos, foi contado mensalmente, ao longo de um ano, e os caranguejos capturados foram sexados e medidos quanto à largura da carapaça, sendo posteriormente liberados. A densidade média de caranguejos foi de 2,5 ind. $\mathrm{m}^{-2}$. A maior densidade (3,9 ind. $\left.\mathrm{m}^{-2}\right)$, juntamente com o maior número de jovens, foi encontrada na parte superior do estuário, correlacionada com baixas salinidades. Nos níveis mais altos de maré a densidade de caranguejos sempre foi alta, exceto na região superior do estuário. Os machos foram menores do que as fêmeas; o tamanho médio da carapaça da população total foi de $4,89 \mathrm{~cm}$, abaixo do tamanho legal permitido para captura $(6 \mathrm{~cm})$. A predominância de fêmeas sobre machos em alguns pontos, principalmente próximos às vilas, revela o avançado nível de sobreexplotação da população de U. cordatus, evidenciando a necessidade urgente de ações fiscalizadoras.

Descriptors: Mangrove crab, Estuarine salinity gradient, Brazilian mangrove forests, Intertidal distribution.

Descritores: Caranguejo de mangue, Gradiente estuarino de salinidade, Manguezais brasileiros, Distribuição no entremarés.

\section{INTRODUCTION}

The semi-terrestrial crab Ucides cordatus cordatus (Linnaeus, 1763) is one of the most abundant species of Brazilian mangrove crabs, representing up to $76 \%$ of the benthic biomass in these mangrove ecosystems (KOCH and WOLFF, 2002). Endemic from Florida (USA) to the South Brazilian coast, this species exhibits territorial behaviour, living in individual burrows up to 2 meters deep (COSTA, 1979; KOCH and WOLFF, 2002). U. cordatus play a very important ecological role in mangrove areas, because its burrow activity is essential for soil drainage and aeration, and nutrient exchange between 
water and sediments (COSTA, 1979; MICHELI, 1993; NORDHAUS et al., 2006). The litter consumption by this crab accelerates nutrient cycling and represents an important input in mangrove productivity, through nutrient retention (MACINTOSH, 1988; LEE, 1998; $\mathrm{KOCH}$ and WOLFF, 2002; NORDHAUS et al., 2006). Many authors have considered $U$. cordatus a keystone species for Brazilian mangrove forests due to its important ecological role in the mangrove ecosystems (SCHORIES et al., 2003; DIELE et al., 2005).

Besides its ecological importance, $U$. cordatus represents a valuable fishery resource, exploited by local fishermen, both for their subsistence and also as a cash income source (CASTRO, 1986; HATTORI and PINHEIRO, 2003; SCHORIES et al., 2003; ALVES et al., 2005). Nowadays, the strong human pressure on natural populations due to uncontrolled catches, habitat destruction or diseases (BOEGER et al., 2005) can cause a decrease in the stock size, the consequences of which have been but little studied. Estimates of the population density of $U$. cordatus in Brazilian mangrove forests differ significantly between studies: ALCÂNTARA-FILHO (1978) found 4.75 ind. $\mathrm{m}^{-2}$ on the northeastern coast (Ceará river) while BRANCO (1993) registered 1.1 ind. $\mathrm{m}^{-2}$ in South Brazil, but differences in crab densities may be related to primary productivity, patterns of larval recruitment, level of crab exploitation, or even to their catchability, as the methods used by each researcher may vary greatly. In spite of the importance of $U$. cordatus to the ecosystem as well as to artisanal fishery, there are few studies focusing on the population ecology of this species in Southeastern Brazil (GÓES, 2003).

The aim of this study was to determine the spatial and temporal distribution of $U$. cordatus in a tropical estuary, along a salinity gradient (lower, middle and upper estuary zone) and along the intertidal level of air exposure (low, medium and high intertidal level) on the Piraquê-açu river estuary, in Southeastern Brazil.

\section{Material and Methods}

\section{Study Area}

The study was undertaken along the Piraquêaçu river estuary $\left(19^{\circ} 54^{\prime} \mathrm{S} ; 40^{\circ} 10^{\prime} \mathrm{W}\right)$, in the municipality of Aracruz, Espírito Santo State, Southeastern Brazil (Fig. 1). This estuary is part of a complex estuarine system that is linked to the Piraquêmirim river. It presents a luxuriant mangrove forest $(1,234$ ha), dominated by the red mangrove Rhizophora mangle bordering the channel (forming an almost monospecific fringe, that delimits the aquatic and intertidal domains, representing $60 \%$ of the floristic composition, with densities of $11.72 \mathrm{ind} / \mathrm{m}^{2}$, Laguncularia racemosa with $32.7 \%$ of arboreal species $\left(6.44 \mathrm{ind} / \mathrm{m}^{2}\right)$, dominating the upper estuary, and the black mangrove Avicennia schaueriana only on the lower and middle estuary, with $7.3 \%$ of mangrove trees $\left(1.44 \mathrm{ind} / \mathrm{m}^{2}\right)$. The total average height of the trees was $6.63 \mathrm{~m}( \pm 2.9 \mathrm{~m})$ and the average DAP was $8.88 \mathrm{~cm}( \pm 7.8 \mathrm{~cm})$ (DEPIZZOL et al, unpublished $\mathrm{ms}$.). The mean tidal range is $0.8 \mathrm{~m}$ but semidiurnal spring tides can exceed $2 \mathrm{~m}$. Mean annual rainfall is 1,309 mm (ANA, 2006), with a rainy season between October and March. Estuarine stratification is weak, due to low volumes of freshwater input (MAGRIS and LOUREIRO-FERNANDES, 2005).

From Setember/2004 to August/2005, three sites were randomly established along the Piraquê-açu river estuary, following a salinity gradient (lower, middle and upper estuary). Site 1 (T1) was located near the river mouth (lower estuary, with $306 \mathrm{~m}$ of intertidal flooded extension, with the 3 species of mangrove tree, A. schaueriana being the tallest one, up to $7.7 \mathrm{~m}$ high, though numerically less frequent), Site 2 (T2), located in the middle zone $(159 \mathrm{~m}$ in extent, in the vicinity of a small fishing village, $R$. mangle being the tallest tree, $7.6 \mathrm{~m}$ in height, and numerically dominant, just as in T1). Site 3 (T3) was in the upper estuarine zone (with $115 \mathrm{~m}$ of intertidal flooded extension, dominated by L. racemosa of $6.6 \mathrm{~m}$ high, with some $R$. mangle of $12.1 \mathrm{~m}$ high) (DEPIZZOL et al, unpublished ms.) (Fig. 1). At each site, one fixed transect perpendicular to the river, ranging from the lower to upper intertidal level was marked out by a rope. On each transect, three plots of $10 \mathrm{~m}^{2}$ each $(1 \mathrm{~m} \times 10 \mathrm{~m}$, subdivided into subplots of $1 \mathrm{~m}^{2}$ ) were delimited within the intertidal zone: the first plot was close to the channel (F1), the second at the mean intertidal level (F2) and the third on the higher intertidal level (F3), locally called "apicum" (Fig. 1).

\section{Environmental Parameters}

Monthly, during the low spring tides, the air temperature (in the shade), the surface sediment and crab burrow water temperatures were determined with a thermometer. Water samples from open and sealed crab burrows were collected for laboratory analysis of salinity and $\mathrm{pH}$, with a refractometer and peagameter. A sample of the sediment $(100 \mathrm{~g})$ from each plot and site was analyzed for particle size composition and organic matter contents, after being dried at $60^{\circ} \mathrm{C}$ and sieved through granulometric meshes $(500,250,125$ and $62.5 \mu \mathrm{m})$ and weighed. The organic matter content of each sample was determined by burning $5 \mathrm{~g}$ of the sediment in an oven $\left(550^{\circ} \mathrm{C}\right.$ for $\left.2 \mathrm{~h}\right)$. The organic matter content was determined as the difference in weight before and after incineration. 


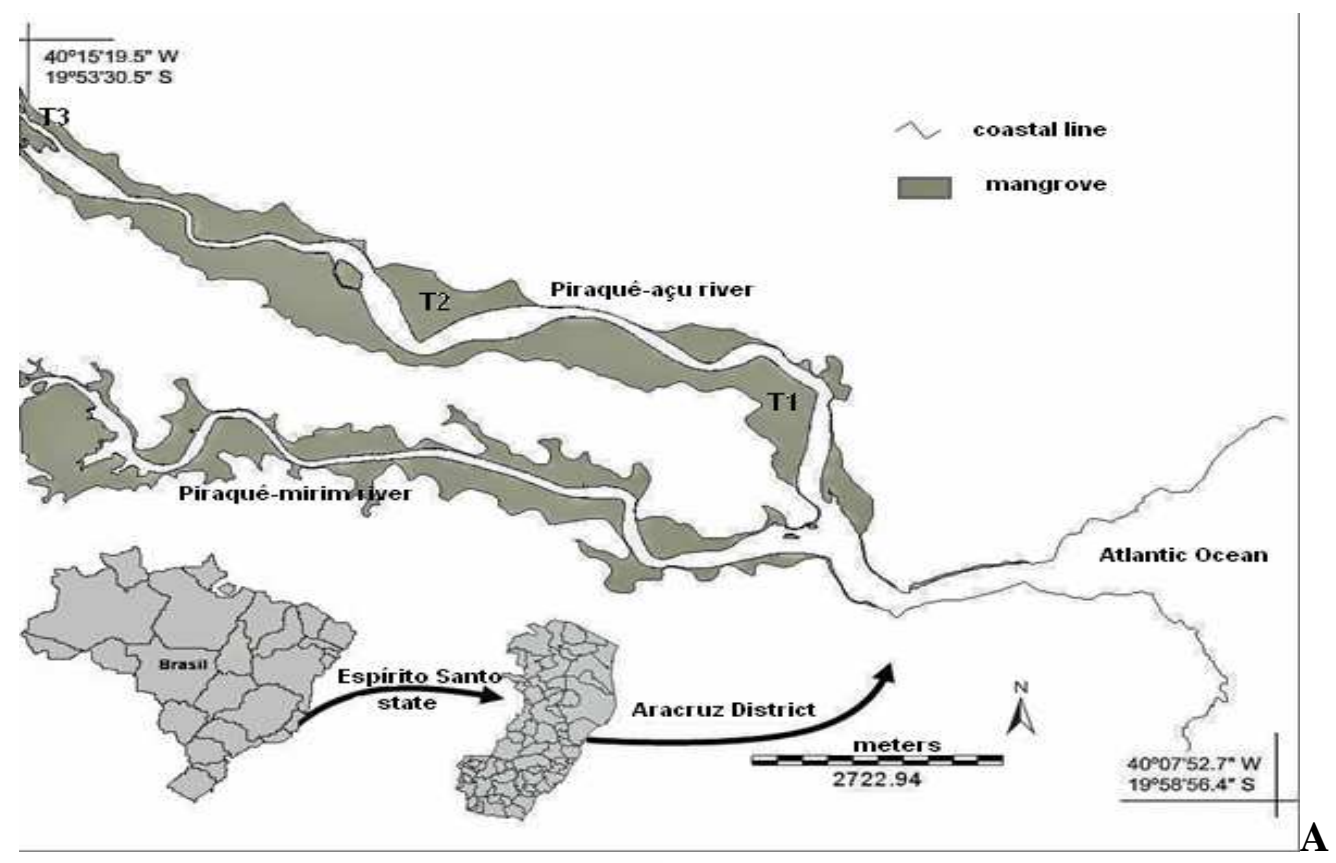

B

Fig. 1. A: Location of sampling sites on the Piraquê-açu river estuary (Aracruz), Espírito Santo, Brazil. T1, T2 and T3 indicate the study sites, in the lower, middle and upper estuary, respectively. B: Diagram showing the 3 estuarine sites with the distribution of mangrove intertidal levels sampled.

\section{Crabs and Burrow Samplings}

Monthly samplings were taken at each intertidal level and site during diurnal low tides. Empty burrows were not registered. All crabs caught had their carapace width measured with a vernier caliper and sex determined according to the abdominal morphology (PINHEIRO et al., 2005). The crabs were released after measurement. Specimens $>4.5 \mathrm{~cm}$ of carapace width were considered adults (SAMPAIO, 2002). All the Ucides cordatus and their burrows (open or sealed) were counted. To determine the crab density (ind.$/ \mathrm{m}^{2}$ ), each burrow (open or sealed) was considered as being inhabited by a single crab
(COSTA, 1979; ALVES et al. 2005). The presence of ovigerous females was also registered, so that the reproduction period of $U$. cordatus in our study area could be determined.

\section{Statistical Analysis}

We used three-way analyses of variance (ANOVA) to test whether environmental parameters (salinity, $\mathrm{pH}$, temperatures of air, sediment and burrow water), the number of crab burrows, juveniles, adults and ovigerous females differed among estuarine sites and intertidal levels over the year. The Tukey test was 
used for post-hoc comparisons (Zar, 1996). Student ttest was used to compare the numbers of juveniles and adults at the three estuarine sites and intertidal levels. The $\chi^{2}$ test was used to test whether the male:female proportion differed from 50:50. Pearson's correlations were used to test for linear relationships among environmental parameters and the number of juveniles and adults and the total number of crab burrows.

\section{RESULTS}

Environmental Parameters

Minimum and maximum temperatures were recorded in July (air: $22.7^{\circ} \mathrm{C}$, sediment: $22.6^{\circ} \mathrm{C}$, burrow water: $22.4^{\circ} \mathrm{C}$ ) and March, respectively (air: $27.7^{\circ} \mathrm{C}$, sediment: $28.3^{\circ} \mathrm{C}$, burrow water: $27^{\circ} \mathrm{C}$ ). In any given month the temperatures were similar among sites. The upper intertidal levels always had the highest air and sediment temperatures (Table 1). Burrow water temperatures exhibited smaller annual variations than did the air temperature (Table 1 and 2).

The lowest burrow water salinities were verified in February at the lower estuarine site T1: $16 \%$ ( \pm 4$)$, in March at $\mathrm{T} 2: 3 \%$ ( \pm 1$)$ and from February to July at the upper estuarine T3, when salinity was $0 \%$. The highest values occurred in September at T1: $41( \pm 8)$ and T3: $18( \pm 1)$, and in
October at T2: $29( \pm 1)$. These salinities varied significantly over the months $(p<0.01$; Table 2$)$. The salinities of channel water and burrow water also varied significantly $(p<0.001)$ among the three sites; the highest values being registered at $\mathrm{T} 1$, decreasing towards the upper estuary (T3) (Table 1 and 2), revealing that the three areas are clearly different and exhibit a salinity gradient. When considering the intertidal zone, higher salinity and range occurred at the upper intertidal level of T1 $(p<0.05)$ (Table 1 and 2 ). The highest temperatures reflect the highest potential for evaporation.

Crab burrow waters tended to be acid, mainly in September, with the lowest value $(5.7 \pm$ 0.66 ) at $\mathrm{T} 3$ (Table 1), the highest $\mathrm{pH}$ occurring in March $(7.5 \pm 0.43)$. The channel water $\mathrm{pH}$ was significantly different among transects $(p<0.05)$ (Table 2). The burrow water $\mathrm{pH}$ was significantly different $(p<0.001)$ over the months and transects, but there were no differences among intertidal levels (Table 2).

The sediment was predominantly sandy mud in all samples, with at least $56 \%$ of sand, except at the medium intertidal level of T2, with $18 \%$ of sand, with no differences in sand percentage detected $(p>0.05)$. The organic matter in the sediment varied from 7.8 to $24.5 \%$, with no spatial differences (Table 1 and 2).

Table 1. Range (minimum-maximum) of environmental parameters of air, water and sediment of the mangrove sites of the Piraquê-açu river estuary, Espírito Santo, Brazil. Samples from September/2004 to August/2005.

\begin{tabular}{|c|c|c|c|c|c|c|c|c|c|}
\hline \multirow{3}{*}{$\begin{array}{l}\text { Estuarine } \\
\text { sites }\end{array}$} & \multicolumn{3}{|c|}{ Lower (T1) } & \multicolumn{3}{|c|}{ Middle (T2) } & \multicolumn{3}{|c|}{ Upper (T3) } \\
\hline & \multicolumn{9}{|c|}{ Intertidal levels } \\
\hline & $\begin{array}{l}\text { Low } \\
(\mathrm{F} 1)\end{array}$ & $\begin{array}{l}\text { Medium } \\
\quad(\mathrm{F} 2)\end{array}$ & $\begin{array}{l}\text { High } \\
\text { (F3) }\end{array}$ & $\begin{array}{l}\text { Low } \\
(\mathrm{F} 1)\end{array}$ & $\begin{array}{l}\text { Medium } \\
(\mathrm{F} 2)\end{array}$ & $\begin{array}{l}\text { High } \\
\text { (F3) }\end{array}$ & $\begin{array}{l}\text { Low } \\
(\mathrm{F} 1)\end{array}$ & $\begin{array}{l}\text { Medium } \\
\quad(\mathrm{F} 2)\end{array}$ & $\begin{array}{l}\text { High } \\
\text { (F3) }\end{array}$ \\
\hline Temperature & & & & & & & & & \\
\hline $\begin{array}{c}\left({ }^{\circ} \mathbf{C}\right) \\
\text { Air }\end{array}$ & $21.2-27$ & $21.7-28.3$ & $22.3-31.3$ & $20.8-28$ & $21.5-27.7$ & $21.8-29.7$ & $20.3-30.3$ & $20-31.2$ & $20.7-32.7$ \\
\hline Sediment & $22.1-27.8$ & $23-29.3$ & $22.8-29.6$ & $21.4-28.2$ & $21.8-28.3$ & $23.8-30.3$ & $21.7-29.4$ & $22.2-28.5$ & $22.8-29.8$ \\
\hline Burrow water & $21.8-26.9$ & $22.3-27.7$ & $22.8-28.3$ & $21.6-27.1$ & $21.2-27.8$ & $23.5-28.9$ & $22.2-28.6$ & $22.3-28.3$ & $22.3-28.5$ \\
\hline $\begin{array}{l}\text { Salinity } \\
\text { channel }\end{array}$ & $0-34.3$ & & & $0-26.3$ & & & $0-7$ & & \\
\hline Burrow & $17.8-37.1$ & $10.6-37.4$ & $19.8-49.9$ & $3-28.3$ & $2.6-28.1$ & $1.7-30.7$ & $0-19.5$ & $0-17.3$ & $0-17.8$ \\
\hline pH channel & $5.9-7.9$ & & & $6.8-7.6$ & & & $5.7-7.9$ & & \\
\hline Burrow & $6.2-8$ & $5.9-7.8$ & $5.9-7.9$ & $5.7-7.8$ & $6.4-7.8$ & $6.4-7.8$ & $3.9-7.9$ & $4.8-7.9$ & $5.3-7.9$ \\
\hline $\begin{array}{c}\text { OrganicMatter } \\
\text { of sediment } \\
(\%)\end{array}$ & 20.9 & 24.5 & 12.8 & 17.6 & 18.2 & 14.7 & 15.6 & 15.7 & 7.8 \\
\hline Sand $(\%)$ & 67 & 72 & 66 & 57 & 18 & 69 & 56 & 81 & 82 \\
\hline Silt/clay (\%) & 33 & 28 & 34 & 43 & 82 & 31 & 44 & 19 & 18 \\
\hline
\end{tabular}


Table 2. Results of 3-way ANOVA and Tukey's test for the environmental parameters from the sites (T1, T2 and T3) and intertidal levels (F1, F2 and F3) of Piraquê-açu river estuary, Espírito Santo, Brazil.

$\mathrm{NS}=$ not significant

\begin{tabular}{|c|c|c|c|c|c|c|}
\hline Variable & \multicolumn{2}{|c|}{$\begin{array}{c}\text { Source of } \\
\text { Variability }\end{array}$} & $\boldsymbol{F}$ & $P(<0.05)$ & interaction & Tukey's Test \\
\hline \multirow{4}{*}{$\begin{array}{c}\text { Air } \\
\text { Temperature }\end{array}$} & \multicolumn{2}{|l|}{ Site } & 0.335 & NS & \multicolumn{2}{|l|}{ Site* level NS } \\
\hline & & $\mathrm{T} 1$ & 3.842 & $<0.05$ & \multirow[b]{2}{*}{$\begin{array}{c}\text { Site* Month } \\
\text { NS }\end{array}$} & \multirow[t]{3}{*}{$\mathrm{F} 1=\mathrm{F} 2 ; \mathrm{F} 2=\mathrm{F} 3$} \\
\hline & \multirow[t]{2}{*}{ Level } & $\mathrm{T} 2$ & 0.487 & NS & & \\
\hline & & $\mathrm{T} 3$ & 0.081 & NS & Level* & \\
\hline & & & & & & Jun Jul Aug Sep Oct Nov Feb Apr May Dec Jan Mar \\
\hline & \multicolumn{2}{|l|}{ Month } & 6.110 & $<0.001$ & Month NS & $\bar{c}$ \\
\hline \multirow[t]{2}{*}{ Sediment } & \multicolumn{2}{|l|}{ Site } & 0.625 & NS & \multirow[t]{2}{*}{ Site* level NS } & \\
\hline & & $\mathrm{T} 1$ & 1.837 & NS & & \\
\hline \multirow[t]{4}{*}{ Temperature } & \multirow[t]{3}{*}{ Level } & $\mathrm{T} 2$ & 4.161 & $<0.05$ & \multirow{2}{*}{$\begin{array}{c}\text { Site* } \\
\text { Month NS }\end{array}$} & $\mathrm{F} 1=\mathrm{F} 2 ; \mathrm{F} 2=\mathrm{F} 3$ \\
\hline & & $\mathrm{T} 3$ & 0.762 & NS & & \\
\hline & & & & & \multirow{4}{*}{$\begin{array}{c}\text { Level* } \\
\text { Month NS } \\
\text { Site* level } \\
\text { NS }\end{array}$} & $\underline{\text { Jul Jun Sep May Aug Oct Nov Dec Feb Apr Jan Mar }}$ \\
\hline & \multicolumn{2}{|l|}{ Month } & 14.074 & $<0.001$ & & \\
\hline \multirow{3}{*}{$\begin{array}{c}\text { Water } \\
\text { temperature } \\
\text { of }\end{array}$} & Site & & 1.404 & NS & & \\
\hline & & $\mathrm{T} 1$ & 0.813 & NS & & \\
\hline & Level & $\mathrm{T} 2$ & 2.159 & NS & Site* & \\
\hline \multirow{2}{*}{ Crab burrow } & & $\mathrm{T} 3$ & 0.488 & NS & Month NS & \multirow[b]{2}{*}{$\underline{\text { Jul Jun Sep May Aug Nov Oct Feb Apr Dec Jan Mar }}$} \\
\hline & \multicolumn{2}{|l|}{ Month } & 21.020 & $<0.001$ & $\begin{array}{c}\text { Level* } \\
\text { Month NS }\end{array}$ & \\
\hline $\begin{array}{l}\text { Water salinity } \\
\text { of river }\end{array}$ & \multicolumn{2}{|l|}{ Site } & 14.456 & $<0.001$ & Site*month & \multirow[t]{2}{*}{$\mathrm{T} 1 \neq \mathrm{T} 2 \neq \mathrm{T} 3$} \\
\hline Channel & \multicolumn{2}{|l|}{ Month } & & NS & NS & \\
\hline Water salinity & Site & & 89.375 & $<0.001$ & Site* level NS & $\mathrm{T} 1 \neq \mathrm{T} 2 \neq \mathrm{T} 3$ \\
\hline & & $\mathrm{T} 1$ & 4.325 & $<0.05$ & & $\mathrm{~F} 1=\mathrm{F} 2 ; \mathrm{F} 1=\mathrm{F} 3$ \\
\hline $\begin{array}{l}\text { of crab } \\
\text { burrow }\end{array}$ & Level & $\mathrm{T} 2$ & 0.009 & NS & Site* & \\
\hline & & $\mathrm{T} 3$ & 0.029 & NS & Month NS & \\
\hline & & & & & Level* & $\underline{\text { Jun Feb Mar Apr Jan May Jul Aug Dec Nov Sep Oct }}$ \\
\hline & Month & & 2.733 & $<0.01$ & Month NS & \\
\hline Water pH of & Site & & 4.403 & $<0.05$ & Site*month & $\mathrm{T} 1=\mathrm{T} 2 ; \mathrm{T} 1=\mathrm{T} 3$ \\
\hline River channel & Month & & 1.329 & NS & NS & \\
\hline water $\mathrm{pH}$ of & Site & & 14.366 & $<0.001$ & Site* level & $\mathrm{T} 1=\mathrm{T} 2$ \\
\hline & & $\mathrm{T} 1$ & 0.895 & NS & NS & \\
\hline Crab burrow & Level & $\mathrm{T} 2$ & 0.104 & NS & Site* & \\
\hline & & $\mathrm{T} 3$ & 0.636 & NS & Month NS & \\
\hline & Month & & 5608 & $<0001$ & Level* $^{*}$ & Sep Oct Nov Dec Jan Jul Aug Feb Apr Jun May Mar \\
\hline & VOUIII & & 5.000 & 0.001 & guotitivs & \\
\hline$\%$ of sand & Site & & 1.695 & NS & & \\
\hline $\begin{array}{c}\% \text { of silt-clay } \\
\% \text { of organic } \\
\text { matter of } \\
\text { sediment }\end{array}$ & Site & & 1.695 & NS & & \\
\hline
\end{tabular}

Burrow Density

A total of 7,996 crab burrows were counted. Open burrows predominated from September to April, when the crabs were also more frequent; sealed burrows dominated from May to August, when crabs c hange their carapace and are soft (Fig. 2). The majority of burrows were registered in the upper 
estuarine area T3: $52.3 \%$, while the lower areas $\mathrm{T} 1$ and $\mathrm{T} 2$ had $24.7 \%$ and $23 \%$, respectively. Assuming that each burrow (open or sealed) was inhabited by a single crab, the mean crab density in the mangrove forest of the Piraquê-açu river estuary was $2.5( \pm 1.2)$ ind. $\mathrm{m}^{-2}$. T3 had a significantly higher density of crabs than T1 and T2 $(p<0.001)$ (Table 3). The high intertidal levels of $\mathrm{T} 1$ and $\mathrm{T} 2$ had higher numbers of crabs $(p<0.001)$, while at T3 the crabs were equally abundant throughout the intertidal zone. The number of burrows was negatively correlated with burrow water salinity $(\rho=-0.275 ; p<0.01)$ and with $\mathrm{pH}(\rho=-$ $0.389 ; p<0.001)$ but a positive correlation was found with air temperature $(\rho=0.232 ; p<0.05)$.

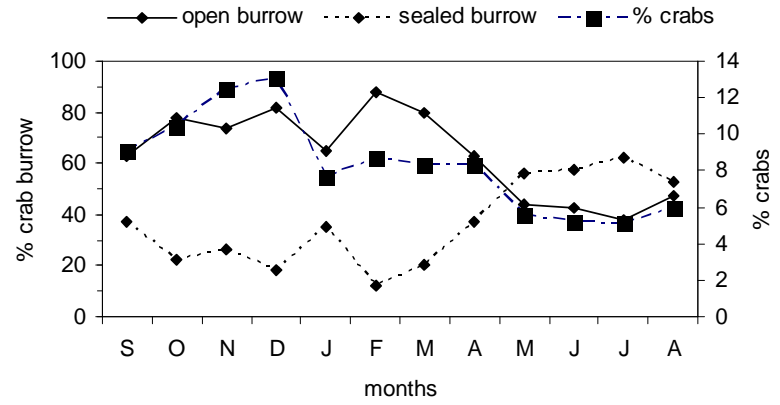

Fig. 2. Relative abundance of opened and sealed crab burrows and the total number of captured mangrove crabs Ucides cordatus on the Piraquê-açu river estuary, Espírito Santo, Brazil, from Setember/2004 to August/2005.

Table 3. Results of 3-way ANOVA and Tukey's test for total number of crab burrows, total number of crab juveniles and adults and ovigerous females at the sites (T1,T2 and T3), intertidal levels (F1, F2 and F3) and by month in the Piraquê-açu river estuary, Espírito Santo, Brazil. NS = not significant

\begin{tabular}{|c|c|c|c|c|c|c|}
\hline \multirow{3}{*}{$\begin{array}{l}\quad \text { Variable } \\
\text { Number of } \\
\text { Burrows }\end{array}$} & \multicolumn{2}{|c|}{$\begin{array}{c}\text { Source of } \\
\text { variability }\end{array}$} & \multirow{2}{*}{$\begin{array}{c}F \\
36.835\end{array}$} & \multirow{2}{*}{$\begin{array}{l}p<0.05 \\
<0.001\end{array}$} & Interaction & \multirow[t]{2}{*}{ Tukey's test } \\
\hline & Sites & & & & Site*level NS & \\
\hline & & $\mathrm{T} 1$ & 28.587 & $<0.001$ & & $\mathrm{~F} 1 \neq \mathrm{F} 2 \neq \mathrm{F} 3$ \\
\hline & Level & $\mathrm{T} 2$ & 31.861 & $<0.001$ & Level*months NS & $\mathrm{F} 1 \neq \mathrm{F} 2 \neq \mathrm{F} 3$ \\
\hline & & T3 & 3.013 & ns & & \\
\hline & Months & & 0.528 & ns & Months* sites NS & \\
\hline Total of & Sites & & 7.504 & $<0.01$ & Site*level NS & $\mathrm{T} 1=\mathrm{T} 3$ \\
\hline Juvenile & & $\mathrm{T} 1$ & 30.662 & $<0.001$ & Level*months NS & $\mathrm{F} 1=\mathrm{F} 2$ \\
\hline \multirow[t]{4}{*}{ Crabs } & level & $\mathrm{T} 2$ & 5.620 & $<0.01$ & Months* sites NS & $\mathrm{F} 1=\mathrm{F} 2 ; \mathrm{F} 1=\mathrm{F} 3$ \\
\hline & & $\mathrm{T} 3$ & 9.869 & $<0.001$ & & $\mathrm{~F} 2=\mathrm{F} 3$ \\
\hline & Months & & 0.484 & NS & & \\
\hline & Sites & & 8.405 & $<0.001$ & Site*level NS & $\mathrm{T} 1=\mathrm{T} 2 ; \mathrm{T} 2=\mathrm{T} 3$ \\
\hline Total of adult & & $\mathrm{T} 1$ & 16.743 & $<0.001$ & Level*months NS & $\mathrm{F} 1 \neq \mathrm{F} 2 \neq \mathrm{F} 3$ \\
\hline \multirow[t]{3}{*}{ Crabs } & Level & $\mathrm{T} 2$ & 7.421 & $<0.01$ & Months* sites NS & $\mathrm{F} 2=\mathrm{F} 3$ \\
\hline & & $\mathrm{T} 3$ & 0.236 & NS & & \\
\hline & Months & & 1.602 & NS & & \\
\hline Total of & Sites & & 1.047 & NS & Site*level NS & \\
\hline Ovigerous & & $\mathrm{T} 1$ & 3.415 & $<0.05$ & Level*months NS & $\mathrm{F} 1=\mathrm{F} 2 ; \mathrm{F} 2=\mathrm{F} 3$ \\
\hline \multirow[t]{4}{*}{ Females } & Level & $\mathrm{T} 2$ & 2.341 & NS & Months* sites NS & \\
\hline & & $\mathrm{T} 3$ & 2.615 & NS & & \\
\hline & & & & & \multicolumn{2}{|c|}{ 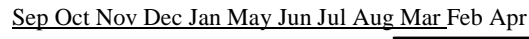 } \\
\hline & Months & & 2.888 & $<0.01$ & & \\
\hline
\end{tabular}


Population Structure

A total of 1,524 crabs were caught, representing $19.1 \%$ of the total number of burrows sampled. Crabs from sealed burrows were not removed because they were soft shelled. From September to April (spring to autumn) catches were significantly higher than from May to August (ANOVA: $\mathrm{F}_{(11 ; 96)}=1.899 ; p<0.05$ ) (Fig. 2). Considering all the crabs, the mean carapace width was $4.89 \mathrm{~cm}( \pm 1.43)$. The most abundant size class was $4.0-4.5 \mathrm{~cm}$ (larger juvenile crabs). Only $25.2 \%$ of the crabs had $>6 \mathrm{~cm}$ of carapace width, the legal minimum size for harvesting (Fig. 3). Juvenile crabs were found to be more abundant in T3 and T1 (49.6\% and $39.0 \%$ respectively), and significantly fewer in $\mathrm{T} 2$ $(11.4 \%)(p<0.01)$ (Table 3; Fig. 4). Significantly more adult crabs occurred in $\mathrm{T} 1(47.7 \%)$ and $\mathrm{T} 2$ (33.6\%) (t-Student: $p<0.05$ and $p<0.001$ ) than in T3 (18.7\%; t-Student: $p<0.05)$, with carapace width of 6.0-6.5 cm and 5.5-6.0 cm, respectively, more frequent. At T3, juvenile crabs dominated, more frequently with 4.0-4.5 cm of carapace width (Fig. 4). Adult crabs were significantly more abundant at the lower intertidal levels of T1 and T2 $(p<0.01)$, but on T3 adult crabs were found to be evenly distributed ( $p$
$>0.05$ ), whereas juveniles were concentrated on the low intertidal levels $(p<0.001)$ (Table 3; Fig. 4).

The number of juvenile crabs was positively correlated only with air temperature $(\rho=0.222 ; p<$ 0.05 ), demonstrating that they occur under less dense canopy coverage, at high intertidal levels. Adult crabs were positively correlated with salinity $(\rho=0.302 ; p<$ $0.01)$ and organic matter content of sediment $(\rho=$ $0.791 ; p<0.05)$, corroborating their higher abundance near the estuary mouth and at low intertidal levels.

Male crabs with carapace width of from 4.0 to $5.0 \mathrm{~cm}$ were more frequent, though ranging from $0.6 \mathrm{~cm}$ to $8.47 \mathrm{~cm}$. Female crabs ranged from 1.0 to $7.83 \mathrm{~cm}$, being more common between 4.0 and $4.5 \mathrm{~cm}$ (Fig. 3). Only $24 \%$ and $28 \%$ of male and female, respectively, were bigger than $6.0 \mathrm{~cm}$, the legal harvest size. Males were significantly smaller than females, with a mean carapace width of $4.77 \mathrm{~cm}$ $( \pm 1.47)$ vs. $4.98 \mathrm{~cm}( \pm 1.39)$ for females (t-Student $=$ 2.884; $p<0.01)$. When considering all the sites, at T2 this pattern was repeated (t-Student $=-3.009 ; p<0.01$ ) but at T3 males were larger than females (tStudent $=3.599 ; \quad p<0.01)$; at $\mathrm{T} 1$ there was no difference.

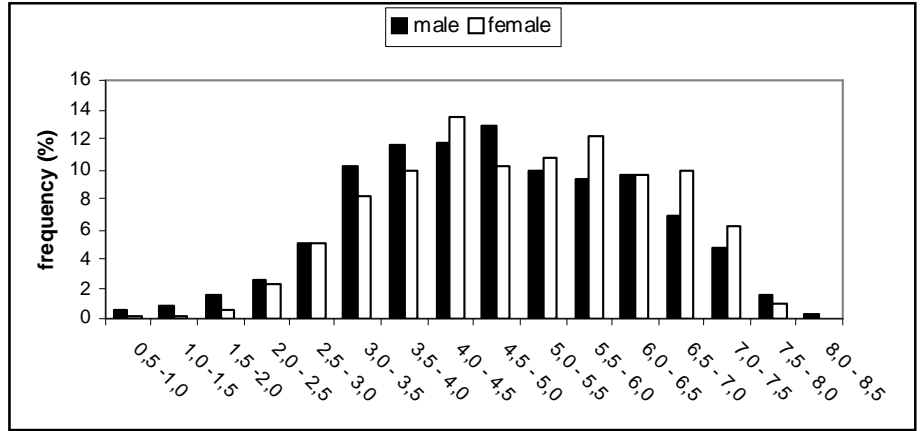

Fig. 3. Size-frequency distribution of male and female mangrove crab Ucides cordatus on the Piraquê-açu river estuary, Espírito Santo, Brazil.

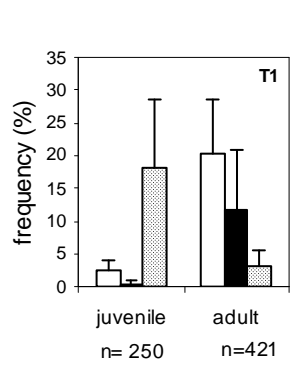

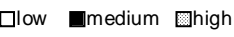
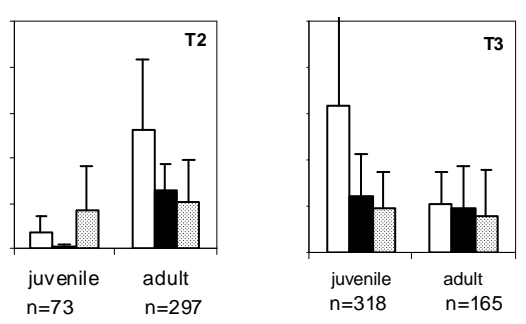

Fig. 4. Relative abundance of juvenile and adult Ucides cordatus crabs along the intertidal level (low, medium and high intertidal) at three sites (T1=lower estuary, T2: middle and T3: upper estuary) on the Piraquê-açu river estuary, Espírito Santo, Brazil. Juvenile crabs are $<4.5 \mathrm{~cm}$ carapace length. 
Table 4. Number of male and female crabs Ucides cordatus, sex-ratio and $\chi^{2}$ test for crabs caught in the Piraquê-açu river estuary, Espírito Santo, Brazil. * $p<0.05 ; * * p<0.01$; *** $p<0.001$; NS $=$ not significant.

\begin{tabular}{|c|c|c|c|c|c|c|}
\hline Transect/Level of intertidal & Males & Females & $\%$ of males & Sex-ratio & \multicolumn{2}{|l|}{$\chi^{2}$} \\
\hline $\mathrm{T} 1$ & 297 & 374 & 44.26 & $1: 1.2$ & 8.836 & $* *$ \\
\hline Low & 121 & 154 & 44.00 & $1: 1.3$ & 3.96 & $*$ \\
\hline Medium & 50 & 92 & 35.21 & $1: 1.8$ & 12.42 & $* *$ \\
\hline High & 126 & 128 & 49.61 & $1: 1$ & 0.016 & NS \\
\hline $\mathrm{T} 2$ & 134 & 236 & 36.22 & $1: 1.8$ & 28.119 & $* * *$ \\
\hline Low & 58 & 120 & 32.58 & $1: 1.8$ & 21.59 & $* * *$ \\
\hline Medium & 19 & 60 & 24.05 & $1: 3.2$ & 21.28 & $* * *$ \\
\hline High & 57 & 56 & 50.44 & $1: 1$ & 0.009 & NS \\
\hline $\mathrm{T} 3$ & 262 & 221 & 54.24 & 1:0.8 & 3.480 & NS \\
\hline Low & 141 & 110 & 56.18 & 1:0.8 & 3.83 & NS \\
\hline Medium & 62 & 67 & 48.06 & $1: 1.1$ & 0.19 & NS \\
\hline High & 59 & 44 & 57.28 & 1:0.8 & 2.18 & NS \\
\hline Total & 693 & 831 & 45.47 & $1: 1.2$ & 12.496 & $* * *$ \\
\hline
\end{tabular}

Throughout the sites, the proportion of ovigerous females was of $11,51,29,45$ and $8 \%$ between January and May, respectively. However, ovigerous females were more abundant at the low intertidal levels, mainly at T1 ( $p<0.05$; Table 3$)$. The smallest ovigerous female had $3.13 \mathrm{~cm}$ of carapace width.

\section{Sexual Proportion}

The overall relationship between males and females was 1.0:1.2 $(p<0.001)$. Considering the three sites, females predominated over males at $\mathrm{T} 1$ and $\mathrm{T} 2$ ( $p<0.01$ and 0.001 , respectively), at T3 males and females were found in equal numbers $(p>0.05)$ (Table 4). At the lower and medium intertidal levels of $\mathrm{T} 1$ and T2, females were significantly more abundant than males $(p<0.01$ and $p<0.001$, respectively). At high intertidal levels and throughout T3, males and females were equally abundant, with no significant difference $(p>0.05)$ (Table 4).

Females were significantly more abundant in the 4.0-4.5 cm, 5.5-6.0 $\mathrm{cm}$ and 6.5 to $7.5 \mathrm{~cm}$ size classes $(p<0.05)$ (Fig. 3); in the other size classes, males and females occurred in the same proportion. Females predominated over males almost throughout the year, except in December, but this difference was significant only in April $(p<0.05)$ (Fig. 5).

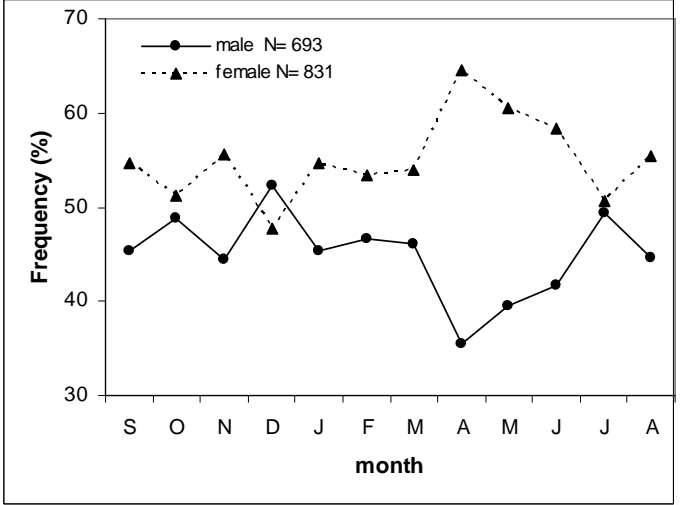

Fig. 5. Frequency of male and female Ucides cordatus crabs captured from Setember/2004 to August/2005 on the Piraquêaçu river estuary, Espírito Santo, Brazil.

\section{Discussion}

\section{Environmental Parameters}

The three sites were similar in relation to environmental parameters such as air, sediment and burrow water temperatures. The higher temperatures registered at upper intertidal levels were due to the less dense canopy cover (mainly of Avicennia schaueriana, that, due to the salinity of the high intertidal levels, 
grow less than Rhizophora mangle). However, salinity varied greatly among the sites, exhibiting a salinity gradient that decreased towards the upper estuary (due to its greater distance from the sea), also observed on the Piraquê-mirim river, a tributary of the Piraquê-açu river (Gilberto Barroso, pers. communication). Seasonal differences in salinity were also observed and related to the rainy season. Higher salinity fluctuation was verified at T1 and T2, mainly at upper intertidal levels, where the mangrove covering is less dense and higher evaporation rates occur, coupled with a higher tidal range. The intertidal range of $\mathrm{T} 3$ was narrow (nearly $1 / 3$ that of $\mathrm{T} 1$ ) and as it flooded at every high tide it prevented any salt concentration. During the wet season, salinities drop almost to freshwater levels, which makes this site more osmotically demanding on Ucides cordatus, whose optimal salinity is from 25 to 30 (OLIVEIRA, 1946). However, DIELE and SIMITH (2006) have pointed out that both juveniles and adults can survive long exposures (> 3 weeks) to freshwater.

Burrow Density

Open burrows were more frequent than sealed ones, revealing the activity of $U$. cordatus, which sealed their burrows only during crab moulting, as a protection against predation (COSTA, 1979; ALVES, 2004). Sealed burrows were more frequent from May to August, coinciding with dry and lower temperature months. According to ATKINSON and TAYLOR (1988) and SPIVAK (1997), many crabs remained inactive in their burrows during the colder months. ALCÂNTARA-FILHO (1978) and NASCIMENTO et al. (1982) suggested that moulting occurred mainly during the dry season. On the Piraquê-açu river estuary, both dry and cold seasons occurred from May to August, corroborating their findings, in spite of the mild tropical winter.

The mean crab density found on the Piraquêaçu river estuary is lower than that registered by ALCÂNTARA-FILHO (1978), COSTA (1979), NASCIMENTO et al. (1982), CASTRO (1986) and GÓES (2003), in other tropical Brazilian mangrove forests, but it is higher than that of a subtropical Brazilian mangrove forest (BRANCO, 1993) or than the mangrove area studied by SCHORIES et al. (2003) and DIELE et al. (2005) in Pará, North Brazil and that studied by ALVES and NISHIDA (2004) in Paraíba, in North-eastern Brazil. These differences can be related to intrinsic factors of a particular mangrove forest (primary productivity, patterns of larval recruitment, among others), or even to the exploitation of crabs or sampling techniques. In general, recent papers have registered smaller crab densities than the older studies, probably revealing that the crab population has been overfished, mainly due to unsustainable practices such as lassos and meshes.

Low crab densities were observed at the low intertidal levels of $\mathrm{T} 1$ and $\mathrm{T} 2$ and are probably related to capture pressure, because these areas are easily harvested (compared to the upper intertidal ones) due to the proximity of small villages and easy accessibility to boats. In other Brazilian mangrove forests, overfishing is also decreasing crab densities (ALVES, 2004; ALVES and NISHIDA, 2004). Juvenile crabs had been found far more frequently at the upper intertidal levels of T1 and T2 and also at T3 on the upper estuary. BLANKENSTEYN et al. (1997) and GÓES (2003) also verified higher crab densities at upper intertidal levels, contrary to the findings of COSTA (1979), NASCIMENTO et al. (1982), BRANCO (1993), who observed a landward reduction in crab densities. This might be due to differences in vegetation structure, as this upper intertidal zone (called "apicum") can be quite different, in terms of species composition and soil type.

The negative correlation of crab burrows and the environmental parameters such as salinity and $\mathrm{pH}$ corroborates the tendency for more juveniles to inhabit both the upper estuary and the intertidal levels, contrasting with the findings of GÓES (2003), who reported a positive correlation between salinity and $\mathrm{pH}$ with crab density, probably because he analyzed the intertidal levels, whereas in our study, both intertidal and the estuarine gradient were sampled. The ability to survive long term exposures to freshwater ( $>3$ weeks) (DIELE and SIMITH, 2006) enables $U$. cordatus to colonize these areas with extreme salinity values. There was also a positive correlation between air temperature and the number of crab burrows, with increased numbers of juveniles at upper intertidal levels, where the black mangrove Avicennia schaueriana dominated, and the canopy coverage was less dense. These upper estuarine and intertidal levels are not, in fact, the most suitable places for crabs, because Rhizophora mangle leaves, from the low intertidal level, are preferred by them (NORDHAUS et al., 2006). Instead, juvenile crabs are displaced to these marginal habitats, probably because adults outcompete over the juveniles in the search for preferred burrowing sites. DIELE et al. (2005) confirmed the preference of adults of $U$. cordatus for shadier inner forest areas, less vulnerable to predation and under $R$. mangle stands.

\section{Population Structure}

The difference between the total number of crab burrows $(7,996)$ and the total number of crabs $(1,524)$ can be attributed to the difficulties encountered in capturing crabs, which frequently burrow down between dense mangrove roots. SCHORIES et al. 
(2003) collected $10 \%$ of the total burrowing crabs sampled; IVO et al. (2000) also had difficulty in catching crabs, differently from NORDHAUS et al., (2006) who showed an average capture efficiency of $73 \%$. During cold months, the present authors collected fewer crabs probably due to their greater inactivity, when they stayed longer and deeper in their burrows (ATKINSON and TAYLOR, 1988; WILSON, 1989; SPIVAK et al., 1994; ALVES 2004; CÉSAR et al.; 2005).

The mean carapace width of the crabs registered on the Piraquê-açu river estuary was below the legal minimum market size of $6.0 \mathrm{~cm}$ (IBAMA, 2003), probably due to overfishing, in spite of capture prohibitions during the reproductive season (a process known locally as "andada").

The dominance of juveniles on the upper estuary could be related to the presence of predators such as fish and paddle crabs on the lower and middle estuary (WILSON, 1989; ALVES and NISHIDA 2002; DANKWA and GORDON, 2002 and KRUMME, 2004), while the upper estuary crabs are less vulnerable to predation. Upper estuarine areas are inundated only during spring tides and remain under water for a shorter time, thus reducing predation risk (GÓES, 2003; PAULA et al., 2003 and KRUMME, 2004). These juveniles can walk down the estuary as they grow older, and enjoy a greater competitive advantage for more suitable locations near riverine areas, with preferred food (leaves of $R$. mangle), soft sediment which facilitates burrowing (NORDHAUS et al., 2006) and proximity to water for spawning. $U$. cordatus prefers $R$. mangle to Avicennia germinans leaves, because they are more easily masticate and digested mechanically (NORDHAUS and WOLFF, 2007).

So $\mathrm{T} 3$ could be considered a nursery area for this semi-terrestrial crab while $\mathrm{T} 1$ and $\mathrm{T} 2$ are reproductive areas. Considering the intertidal level, COSTA (1979), ALVES and NISHIDA (2002) and GÓES (2003) also found more juveniles on the upper intertidal level, and they attributed this to intraspecific competition, because adult crabs prefer a denser canopy covering. On the Piraquê-açu river estuary, a denser canopy covering occurs on the low intertidal level, under $R$. mangle stands, with a higher density by area than is associated with the other two mangrove species.

Male and female crabs of medium carapace width dominated the population, with only $24 \%$ and $28 \%$ of the males and females, respectively, being larger than $6.0 \mathrm{~cm}$, the minimum harvest size. This differs from the findings of ALCÂNTARA-FILHO (1978), CASTRO (1986) and DIELE et al. (2005), who found crabs of around $6 \mathrm{~cm}$ of carapace width as the most frequent size class for males and 5.5 for females. According to HARTNOLL and BRYANT
(1990), long-living species such as $U$. cordatus, which can live at least 10 years (PINHEIRO; et al., 2005), would be expected to form groups of larger sizes, but the present authors verified the opposite, with smaller crabs being the most frequent. DIELE et al. (2005) pointed out that males grow faster than females, due to reproductive investment, so the normal pattern is for males to be larger than females, contrary to the size frequency observed on the Piraquê-açu estuary. Our findings revealed that few individuals of $U$. cordatus can be harvested, suggesting that fishing pressure is beyond the population's replacement capacity.

Ovigerous females were found from January to May, revealing that this is the reproductive season in this mangrove forest, and this differs from the findings of ALCÂNTARA-FILHO (1978), CASTRO (1986), DIELE et al. (2005), SAMPAIO (2002) and PINEIRO et al. (2005), relating to other Brazilian mangrove forests. But all the studies agree that spring and summer are the reproductive season. These females were more frequent at low intertidal levels, favoring spawning. The smallest ovigerous female found $(3.13 \mathrm{~cm}$ of carapace width) was below that reported by other authors such as SAMPAIO (2002) but is close to the findings of DIELE et al. (2005) and PINHEIRO et al. (2005).

\section{Sex Ratio}

Female crabs dominated over male crabs; female dominance was more evident near small villages (as occurred at T2). Males are preferred due to their larger body and claw sizes than those of the females, which render more meat (ALVES and NISHIDA, 2004; DIELE et al., 2005). Females also dominated over males in other mangrove areas (ALCÂNTARA-FILHO, 1978; GÓES, 2003) whereas males were more common in others (NASCIMENTO et al., 1982; CASTRO, 1986; BRANCO, 1993; ALVES and NISHIDA, 2004; DIELE et al., 2005). Among the juveniles, the sex ratio was more even, probably because they are not harvested.

The female crab dominance, the reduced mean size and the size distribution skewed towards females suggest that the population of $U$. cordatus in the mangrove forest of the Piraquê-açu river estuary has been subject to overfishing. $U$. cordatus has been considered a threatened species (ALVES and NISHIDA, 2004). Further, the lethargic crab disease has become widespread in Brazilian mangrove areas (BOEGER et al., 2005). All these facts constitute a menacing scenario which threatens the population's survival. Thus more effective management and conservation measures such as a local interruption of crab collection are necessary to allow the stock to recover. This action is necessary to protect this fisheries resource both for the traditional population as 
well as for the regional culture and economy and the health of the mangrove ecosystem. Meanwhile, more detailed studies on the role of other factors (e.g. the biotic parameters such as predation and intraspecific competition) are needed better to characterize the dynamics of crab populations.

\section{ACKNOWLEDGEMENTS}

Our thanks go to Gabriela B. Depizzol, Edivan G. Ribeiro and Mariana A. Portela for their help in field work and to the crab collectors Juceli C. Santos and Carlos A. Santos for their valuable help. We also thank Adrian R. Beech for revision of the English text, Dr. Gilberto F. Barroso for the map and laboratory support and the anonymous referee for critically reviewing the manuscript.

\section{REFERENCES}

ALCÂNTARA-FILHO, P. Contribuição para o conhecimento da biologia e ecologia do caranguejo-uçá - Ucides cordatus cordatus (Linnaeus, 1763) (Crustacea, Decapoda, Brachyura), no manguezal do Rio Ceará, Brasil. Arq. Cienc. Mar., v.18, p. 1-41, 1978.

ALVES, A. Os argonautas do mangue. IMESP, São Paulo. 2004. 264p

ALVES, R.R.N.; NISHIDA, A.K. A ecdise do caranguejouçá Ucides cordatus L. (Decapoda, Brachyura) na visão dos caranguejeiros. Interciência, v. 27, p. 110-117, 2002.

ALVES, R.R.N.; NISHIDA, A.K. Population structure of the mangrove crab Ucides cordatus (Crustacea: Decapoda; Brachyura) in the estuary of the Mamanguape River, Northeast Brazil. Trop. Oceanograph., v.32, p. 23-37, 2004

ALVES, R.R.N.; NISHIDA, A.K.; HERNÁNDEZ, M.I.M. Environmental perception of gatherers of the crab "caranguejo-uçá" (Ucides cordatus, Decapoda, Brachyura) affecting their collection attitudes. J. Ethnobiol. Ethnomed., v.1, p. 10, 2005.

ANA - National Agency of water. Available at: http://www.ana.gov.br.

ATKINSON, R.J.A.; TAYLOR, A.C. Physiological ecology of burrowing decapods. In: FINCHAM, A.A. RAINBOW, P.S., (Eds.). Aspects of Decapod Crustacean Biology. Zoological Society of London, Clarendon, Oxford, 1988. p. 201-226.

BLANKENSTEYN, A.; CUNHA-FILHO, D.; FREIRE, A.S. Distribuição, estoques pesqueiros e conteúdo protéico do caranguejo do mangue Ucides cordatus (L., 1763) (Brachyura Ocypodidae) nos manguezais da Baía das Laranjeiras e adjacências, Paraná, Brasil. Arq. Biol. Tecnol. v. 40, p. 331-349, 1997.

BOEGER, W.A.; PIE, M.R.; OSTRENSKY, A.; PATELLA, L. Lethargic crab disease: multidisciplinary evidence supports a mycotic etiology. Mem. Inst. Oswaldo Cruz, v. 100, p. 161-167, 2005.
BRANCO, J.O. Aspectos bioecológicos do caranguejo Ucides cordatus (Linnaeus, 1763) (Crustacea: Decapoda) do manguezal de Itacorubi, Santa Catarina, Brasil. Arq. Biol. Tecnol., v. 36, p.133-148, 1993.

CASTRO, A.C.L. Aspectos bio-ecológicos do caranguejouçá, Ucides cordatus cordatus (Linnaeus, 1763), no estuário do Rio dos Cachorros e Estreito do Coqueiro, São Luiz-MA. Bol. Lab. Hidrobiol., v. 7, p. 7-26, 1986.

CÉSAR, I.I.; ARMENDÁRIZ, L.C. ; BECERRA, R.V. Bioecology of the fiddler crab Uca uruguayensis and the burrowing crab Chasmagnathus granulatus (Decapoda, Brachyura) in the Refugio de Vida Silvestre Bahía Samborombón, Argentina. Hydrobiol., v. 545, v. $237-$ 248, 2005.

COSTA, R.S. Bioecologia do caranguejo-uçá, Ucides cordatus (Linnaeus, 1763) Crustacea, Decapoda no nordeste brasileiro. Bol. Cear. Agron., v. 20, p. 1-74, 1979.

DANKWA, H.R.; GORDON, C. The fish and fisheries of the lower Volta mangrove swamps in Ghana. Afr. J. Sci. Technol., v.3, p. 25-32, 2002.

DIELE, K.; KOCH, V.; SAINT-PAUL, U. Population structure, catch composition and CPUE of the artisanally harvested mangrove crab Ucides cordatus (Ocypodidae) in the Caeté estuary, North Brazil: indications for overfishing? Aquat. Living Resour., v.18, p. 169-178, 2005 .

DIELE, K.; SIMITH, D.J.B. Salinity tolerance of northern Brazilian mangrove crab larvae, Ucides cordatus (Ocypodidae): necessity for larval export? Estuar. Coast. Shelf Sci., v. 68, p. 600-608, 2006.

GÓES, P. Aspectos bioecológicos do caranguejo Ucides cordatus (Linnaeus, 1763) no manguezal da baía de Vitória, ES. 2003. M.Sc. graduation, Universidade Federal do Espírito Santo, Brasil.

HARTNOLL, R.G.; BRYANT, A.D. Size-frequency distributions in decapod crustacean- the quick, the dead, and the cast-offs. J. Crust. Biol., v. 10, p. 14-19, 1990.

HATTORI, G.Y.; PINHEIRO, M.A.A. Fertilidade do caranguejo de mangue Ucides cordatus (Linnaeus) (Crustacea, Brachyura, Ocypodidae), em Iguape (São Paulo, Brasil). Rev. Bras. Zool., v. 20, p. 309-313, 2003.

IBAMA, Brazilian Agency of the Environment and Natural Resources. 2003. Law nº52/2003.

IVO, C.T.C.; DIAS, A.F.; BOTELHO, E.R.O.; MOTA, R.I.; VASCONCELOS, J.A.; VASCONCELOS, E.M.S. Caracterização das populações de caranguejo-uçá, Ucides cordatus cordatus (Linnaeus, 1763), capturados em estuários do nordeste do Brasil. Bol. Téc. Cient. CEPENE, v. 8, p. 9-43, 2000.

$\mathrm{KOCH}, \mathrm{V}$.; WOLFF, M. Energy budget and ecological role of mangrove epibenthos in the Caeté estuary, North Brazil. Mar. Ecol. Progr. Ser., v. 228, p. 119-130, 2002.

KRUMME, U. Pattern in the tidal migration of fish in a north Brazilian mangrove channel as revealed by a vertical split-beam echo sounder. Fish. Res., v. 70, p. 1-15, 2004.

LEE, S. Y. Ecological role of grapsid crabs in mangrove ecosystems: a review. Mar. Freshw. Res., v. 49, p. 335343, 1998.

MACINTOSH, D.J. The ecology and physiology of decapods of mangrove swamps. In: FINCHAM, A.A.; RAINBOW, P.S. (Eds.), Aspects of Decapod Crustacean Biology. Zoological Society of London, Clarendon, Oxford, 1988. p. 315-341. 
MAGRIS, R.A.; LOUREIRO-FERNANDES, L.F Levantamento preliminar das larvas de Porcellanidae (Decapoda, Anomura) do sistema estuarino dos rios Piraquê-açu e Piraquê-mirim, Aracruz, Espírito Santo. Braz. J. Aquat. Sci. Technol., v. 9, p. 49-54, 2005.

MICHELI, F. Feeding ecology of mangrove crabs in North Eastern Australia: mangrove litter consumption by Sesarma messa and Sesarma smithii. J. Exp. Mar. Biol. Ecol., v. 171, p. 165-186, 1993.

NASCIMENTO, S.A.; SANTOS, E.R.; BONFIM, L.; COSTA, R.S. Estudo bio-ecológico do caranguejo-uçá (Ucides cordatus) e do manguezal do estado de Sergipe-Nordeste do Brasil. ADEMA, Sergipe, 1982. $45 \mathrm{p}$.

NORDHAUS, I.; WOLFF, M.; DIELE, K. Litter processing and population food intake of the mangrove crab Ucides cordatus in a high intertidal forest in northern Brazil Estuar. Coast. Shelf Sci., v. 67, p. 239-250, 2006.

NORDHAUS, I.; WOLFF, M. Feeding ecology of the mangrove crab Ucides cordatus (Ocypodidae): food choice, food quality and assimilation efficiency. Mar. Biol. v.151, p. 1665-1681, 2007.

OLIVEIRA, L.P.M. Estudos ecológicos dos crustáceos comestíveis uçá e guaiamum, Cardisoma guanhumi Latreire e Ucides cordatus (L.), Gecarcinidae, Brachyura. Mem. Inst. Oswaldo Cruz, v. 44, p. 295323, 1946

PAULA, J.; MENDES, R.N.; MWALUMA, J.; RAEDIG, C. EMMERSON, W. Combined effects of temperature and salinity on larval development of the mangrove crab Parasesarma catenata Ortman, 1897 (Brachyura: Sesarmidae). ICES J. Mar. Sci., v. 2, p. 57-63, 2003.
PINHEIRO, M.A.A; FISCARELLI, A.G.; HATTORI, G.Y. Growth of the mangrove crab Ucides cordatus (Brachyura, Ocypodidae). J. Crust. Biol., v. 25, p. 293301, 2005.

SAMPAIO, F.D.F. Aspectos reprodutivos relacionados à proteção jurídica do caranguejo Ucides cordatus (Linnaeus, 1763) (Crustacea, Decapoda, Brachyura) no Espírito Santo. 2002. M.Sc. graduation, Universidade Federal do Espírito Santo, Brazil. 90p.

SCHORIES, D.; BARLETTA-BERGAN, A.; BARLETA, M.; KRUMME, U.; MEHLIG, U.; RADEMAKER, V. The keystone role of leaf-removing crabs in mangrove forests of North Brazil. Wetlands Ecol. Managem., v.11, p. 243-255, 2003.

SPIVAK, E.D. Cangrejos estuariales del Atlântico sudoccindental (25 $\left.-41^{\circ} \mathrm{S}\right) \quad$ (Crustacea: Decapoda:Brachyura). Invest. Mar., v. 25, p. 105-120, 1997.

SPIVAK, E.D.; ANGER, K.; LUPPI, T.A.; BAS, C.C.; ISMAEL, D. Distribution and habitat preferences of two grapsid crab species in Mar Chiquita Lagoon (Province of Buenos Aires, Argentina). Neritica, v. 10, p. 7-26, 1994.

WILSON, K.A. Ecology of mangrove crabs: predation, physical factors and refuges. Bull. Mar. Sci., v. 44, p. 263-273, 1989.

ZAR, J.H.. Biostatistical Analysis, $3^{\text {th }}$ edition. Prentice Hall, U Upper Saddler River, N.J., 1996. 918 p.

(Manuscript received 06 November 2008; revised 02 June 2009; accepted 11 August 2009) 